\title{
Secretion Of PGC-1 $\alpha$ By Modulating Physical Exercise To Protect Improving Obesity Prevalence
}

\author{
Moch. Nasmay Lupita, Desiana Merawati and Sugiharto* \\ Sport Science Department, Faculty of Sport Science State University of Malang \\ *sugiharto@um.ac.id
}

\begin{abstract}
Physical exercise can modulate the secretion of peroxisome proliferation activated receptor $\gamma$ coactivator-1 $\alpha$ (PGC-1 $\alpha)$ as a prevention strategy to increase the prevalence of obesity. This study aims to analyze the response of physical exercise as a modulation of PGC- $1 \alpha$ to protect against the increasing prevalence of obesity. This research is a true experimental design with the randomized pretest-posttest control group design using 15 obese women aged 18-22 years, Body Mass Index (BMI) $25-35 \mathrm{~kg} / \mathrm{m}^{2}$, normal blood pressure, Resting Heart Rate (RHR) normal, $\mathrm{VO}_{2 \max } 25-35 \mathrm{ml} / \mathrm{kg} / \mathrm{min}$ and randomly divided into three groups, namely CONT ( $\mathrm{n}=5$, Control Without Intervention), MIIE ( $\mathrm{n}=5$, Moderate Intensity Interval Exercise) and MICE ( $\mathrm{n}=5$, Moderate Intensity Continuous Exercise). The intervention was carried out at 07.00-09.00 a.m. MIIE and MICE interventions carried out for 40-45 minutes using a treadmill. Pre-exercise blood sampling and 10 minutes postexercise. Measurement of PGC-1 $\alpha$ levels used the Enzyme-Linked Immunosorbent Assay (ELISA) method. Data analysis techniques used ANOVA test and LSD post hoc test with the Statistical Package for Social Science (SPSS). The results obtained mean PGC-1 $\alpha$ preexercise levels at CONT $(1.733 \pm 1.651) \mathrm{ng} / \mathrm{mL}$, MIIE $(2.465 \pm 1.334) \mathrm{ng} / \mathrm{mL}$ and MICE $(2.198 \pm 0.853) \mathrm{ng} / \mathrm{mL}(\mathrm{p}=0.706)$. The mean PGC-1 $\alpha$ post-exercise levels in CONT $(2.107 \pm 1.603) \mathrm{ng} / \mathrm{mL}$, MIIE $(2.753 \pm 1.093) \mathrm{ng} / \mathrm{mL}$ and MICE $(2.566 \pm 0.843) \mathrm{ng} / \mathrm{mL}$ $(\mathrm{p}=0.717)$. Based on the results of the study it is concluded that there are no significant differences in the mean levels of PGC- $1 \alpha$ pre-exercise and post-exercise in all groups $(P>0.05)$. It is recommended to do further research by providing moderate intensity treadmill exercise intervention which is carried out chronically to increase PGC-1 $\alpha$ levels.
\end{abstract}

Keywords: PGC-1 $1 \alpha$ levels, moderate intensity interval exercise, moderate intensity continuous exercise, obese women 


\section{STRADA Jurnal Ilmiah Kesehatan}

DOI: $10.30994 /$ sjik.v9i2.299

ISSN: 2252-3847 (print); 2614-350X (online)

Vol.9 No.2 November 2020 Page.345-352

\section{BACKGROUND}

Obesity is still a global concern, because the prevalence of obesity continues to increase significantly (Rachmi et al., 2017). In 2015, the prevalence rate of obesity in the world reached $39 \%$ of the total population of all countries. Increased obesity prevalence in detail is divided into developed and developing countries. Increased prevalence in developed countries experienced a significant increase from 1980 amounting to $45.3 \%$ to $64.2 \%$ in 2015. Increased prevalence of obesity in developing countries experienced a significant increase from 1980 amounting to $10.9 \%$ to $24.3 \%$ in 2015 (Chooi et al., 2019), if the trend of bad lifestyle continues, then it is estimated that in 2030 will increase to $38 \%$ overweight and $20 \%$ obese (Kelly et al., 2008). In Indonesia, based on the results of the Basic Health Research (Riskesdas) in 2018, the prevalence of obesity at the age of 18 years old experienced a significant increase from 2007 reaching $10.5 \%$ to $14.8 \%$ in 2013 and in 2018 increasing to $21.8 \%$ (Riskesdas, 2018). The increasing prevalence of obesity in women tends to be higher than in men (Garawi et al., 2014). The increasing prevalence of obesity has been very worrying and poses a very serious threat to public health, especially women (Lobstein and Jackson, 2006).

Obesity is caused by an energy imbalance that results in one of them metabolic syndrome (Collision et al., 2010). Several factors as a cause of obesity include genes (Bell et al., 2005), inactive lifestyle, stress, eating habits and fast food (junk food) (Collision et $a l ., 2010)$. This situation can unconsciously reduce the functional ability of the body as a public health threat (Dinas et al., 2017). Decreased functional ability of the body can change the body's homeostasis with the onset of metabolic syndrome diseases, such as type 2 diabetes mellitus, cardiovascular disease and hypertension (Lobstein and Jackson., 2006) which are worse than these conditions can cause premature death (Collision et al., 2010) . Therefore, a non-pharmacological approach is needed to gradually reduce the prevalence of obesity. Exercise-based weight loss method by modulating browning white fat to brown fat mediated by peroxisome proliferation activated receptor $\gamma$ coactivator- $1 \alpha$ (PGC-1 $\alpha)$ (Dinas et al., 2017) is the right method to be used in preventing the increase in obesity prevalence.

PGC-1 $\alpha$ plays an important role as co-transcription which facilitates various transcription factors to regulate complex tissues, such as being involved in regulating carbohydrate and lipid metabolism in energy formation (Jung and Kim., 2014). Muscle contractions are mediated with $\mathrm{Ca} 2+$ to attach actin and myosin which are conditions for contractions (Sugiharto, 2012). Ca2 + builds up in the muscles to stimulate adenosine monophosphate protein kinase (AMPK) which plays a role in stimulating the enzyme mitogenactivated protein kinase (MAPK) or under another name P38 for energy formation by stimulating PGC-1 $\alpha$ containing disitosol which plays a role in secreting Protein Fibronectin-Type III Domain Containing 5 enzymes (FNDC5), then FNDC5 undergoes the process of breaking down proteins that will be released into the bloodstream called Irisin (Rowe et al., 2010). PGC-1 $\alpha$ has an important role in converting white fat to brown fat through modulating irisin (Dinas et al., 2017).

Increased levels of PGC- $1 \alpha$ can be stimulated through exercise (Jung and Kim, 2014). Exercise with moderate and high intensity has been shown to increase PGC-1 $\alpha$ levels (Dinas et al., 2017), both acute and chronic. Likewise, endurance training with moderate intensity performed acutely increases PGC-1 $\alpha$ levels (Little et al., 2010). Previous studies also showed the same results that endurance training and strength with moderate intensity increased PGC-1 $\alpha$ levels (Norheim et al., 2014). For this reason, the 


\section{STRADA Jurnal Ilmiah Kesehatan}

DOI: $10.30994 /$ sjik.v9i2.299

ISSN: 2252-3847 (print); 2614-350X (online)

Vol.9 No.2 November 2020 Page.345-352

purpose of this study is to analyze the acute response of moderate interval training and continuous intensity to increasing levels of PGC- $1 \alpha$ in obese women.

\section{METHODS}

This research is a true experimental design with the randomized pretest-posttest control group design using 15 obese women aged 18-22 years old, Body Mass Index (BMI) 25-35 $\mathrm{kg} / \mathrm{m}^{2}$, normal blood pressure, Resting Heart Rate (RHR) normal, $\mathrm{VO}_{2 \max } 25-35 \mathrm{ml} / \mathrm{kg} / \mathrm{min}$ and randomly divided into three groups, namely CONT $(\mathrm{n}=5$, Control Without Intervention), MIIE ( $\mathrm{n}=5$, Moderate Intensity Interval Exercise) and MICE ( $\mathrm{n}=5$, Moderate Intensity Continuous Exercise). All of the research procedures were approved by the Medical Research Ethics Commission of the Faculty of Medicine, University of Brawijaya Malang number 26/EC/KEPK-S1/02/2020.

Measurement of height and weight used GEA ZT-120. $\mathrm{VO}_{2 \max }$ measurements used Astrand 6-minute cycle test method using an ergo-cycle (Monark $828 \mathrm{E}$, Version 1010 Art. No: 7950-296, Vansbro, Sweden). Heart rate monitoring used Polar (Polar H10 Heart Rate Sensor, USA, Inc.). Blood pressure was measured using an OMRON digital blood pressure monitor (OMRON Model HEM-7130 L, Omron Co.).

Blood sampling was done in $4 \mathrm{ml}$ cubital veins (Daskalopoulou et al., 2014). When taking blood, the subject is in a sleep position. Blood sampling was done 2 times preexercise and 10 minutes post-exercise. The blood was centrifuged for 15 minutes at 3000 rpm (Tsuchiya et al., 2014; Daskalopoulou et al., 2014). Measurement of PGC-1 $\alpha$ levels used the Enzyme-Linked Immunosorbent Assay (ELISA) kit (Catalog No. E-EL-H1359; Elabscience, Inc., China, 2019) with a standard curve range of $0.16-10 \mathrm{ng} / \mathrm{mL}$ and the level of sensitivity of the PGC- $1 \alpha$ in the kit $0.10 \mathrm{ng} / \mathrm{mL}$.

MIIE intervention was carried out by running on a treadmill with moderate intensity $60-70 \% \mathrm{HR}_{\max }$ for 45 minutes with details of 5 minutes warming $\left(50-60 \% \mathrm{HR}_{\max }\right), 35$ minutes core $\left(5\right.$ minutes work $\left(60-70 \% \mathrm{HR}_{\max }\right)$ interspersed with recovery active on the treadmill for 2.5 minutes $\left(50-60 \% \mathrm{HR}_{\max }\right)$ performed 5 repetitions) and 5 minutes of cooling $\left(50-60 \% \mathrm{HR}_{\max }\right)$. MICE intervention is carried out by running on a treadmill with an intensity of $60-70 \% \mathrm{HR}_{\max }$ for 40 minutes with details of 5 minutes warming (50-60\% $\left.\mathrm{HR}_{\max }\right), 30$ minutes of core carried out continuously $\left(60-70 \% \mathrm{HR}_{\max }\right)$ and 5 minutes cooling $\left(50-60 \% \mathrm{HR}_{\max }\right)$. The intervention was carried out at 07.00-09.00 a.m using a treadmill (Richter Treadmill Semi-Commercial Evolution (4.0 hp dc)).

Data analysis techniques used Statistical Package For Social Science (SPSS) software version 21 (Chicago, IL, USA). The normality test uses the Shapiro-Wilk test, while the homogeneity test uses the Levene test. Data that were normally distributed and had a homogeneous variant were tested using the ANOVA test and continued with a post hoc LSD test with a significant level $(P<0.05)$. All data are displayed with mean \pm SD.

\section{RESULT}

The results of descriptive analysis of the research subjects' characteristics can be seen in table 1 below.

Table. 1 Research Subjects' Characteristics.

\begin{tabular}{lccccccc}
\hline \multirow{3}{*}{ Variable } & \multicolumn{6}{c}{ Group } & \multirow{2}{*}{ p-value } \\
\cline { 2 - 7 } & \multicolumn{2}{c}{ CONT } & \multicolumn{2}{c}{ MIIE } & \multicolumn{2}{c}{ MICE } & \\
\cline { 2 - 7 } & Mean & SD & Mean & SD & Mean & SD & \\
\hline Physiological & & & & & & & \\
\hline SBP $(\mathrm{mmHg})$ & 113.333 & 5.164 & 113.333 & 5.164 & 111.667 & 4.083 & 0.444 \\
\hline
\end{tabular}




\section{STRADA Jurnal Ilmiah Kesehatan}

DOI: $10.30994 /$ sjik.v9i2.299

ISSN: 2252-3847 (print); 2614-350X (online)

Vol.9 No.2 November 2020 Page.345-352

\begin{tabular}{|c|c|c|c|c|c|c|c|}
\hline $\mathrm{DBP}(\mathrm{mmHg})$ & 76.667 & 5.164 & 76.667 & 5.164 & 73.333 & 5.164 & 0.668 \\
\hline RHR (bpm) & 78.14 & 11.35 & 81.37 & 14.68 & 78.38 & 8.45 & 0.835 \\
\hline MHR(bpm) & 199.43 & 0.98 & 199.50 & 1.41421 & 199.38 & 0.74 & 0.974 \\
\hline \multicolumn{8}{|c|}{ Anthropometry } \\
\hline BMI $\left(\mathrm{kg} / \mathrm{m}^{2}\right)$ & 29.850 & 1.601 & 28.850 & 1.992 & 29.017 & 1.583 & 0.346 \\
\hline Age (years) & 20.667 & 1.033 & 21.000 & 1.414 & 20.667 & 0.817 & 0.776 \\
\hline \multicolumn{8}{|l|}{ Physical } \\
\hline $\begin{array}{l}\mathrm{VO}_{2 \max } \\
(\mathrm{ml} / \mathrm{kg} / \mathrm{min})\end{array}$ & 27.407 & 2.374 & 26.270 & 1.104 & 27.383 & 1.348 & 0.146 \\
\hline
\end{tabular}

Note: SBP: Systolic Blood Pressure, DBP: Diastolic Blood Pressure, HR: Resting Heart Rate, MHR: Maximum Heart Rate, BMI: Body Mass Index, $\mathrm{VO}_{2 \max }$ : Volume Oxygen Maximum.

Based on Table 1, ANOVA test showed that there are no significant differences in the mean data characteristics of research subjects in all groups. The results of the analysis of PGC- $1 \alpha$ levels in each group can be seen in Table 2.

Table. 2 Results of Analysis of PGC-1a Levels in EachGroup

\begin{tabular}{|c|c|c|c|c|}
\hline \multirow{2}{*}{$\begin{array}{c}\text { PGC-1a } \\
\text { Level }\end{array}$} & \multicolumn{3}{|c|}{ Group } & \multirow{2}{*}{$\begin{array}{c}\text { ANOVA } \\
P \text {-value }\end{array}$} \\
\hline & $\operatorname{CON}(n=5)$ & MIIE $(n=5)$ & $\operatorname{MICE}(n=5)$ & \\
\hline Pre-exercise & $1.733 \pm 1.651$ & $2.465 \pm 1.334$ & $2.198 \pm 0.853$ & 0.706 \\
\hline Post-exercise & $2.107 \pm 1.603$ & $2.753 \pm 1.093$ & $2.566 \pm 0.843$ & 0.717 \\
\hline
\end{tabular}

Note: All data is displayed with Mean \pm SD.

Based on Table 2, it is showed that there is no significant difference in the mean PGC$1 \alpha$ levels between pre-exercise and post-exercise in all groups $(P>0.05)$.

\section{DISCUSSION}

Based on Anova test on the characteristics of the research subjects, it is showed that there is no significant difference in the average characteristics of the research subjects in all groups with a value of $(P>0.05)$. The study is in line with the results of research conducted by Frank et al. (2003) concluded that there were no significant differences in the characteristics of research subjects which included BMI, Body Fat (BF) and VO2max. This indicates that the researcher controls the data characteristics of the research subjects, so that in all groups there is no difference. PGC-1 $\alpha$ increases with several models, one of which is exercise (Dinas et al., 2017). Training has an important role in increasing the level of PGC- $1 \alpha$. Increased levels of PGC-1 $\alpha$ are in citosol and increased levels of PGC-1 $\alpha$ are in the nucleus (Wright et al., 2007) higher increases in the nucleus (Little et al., 2010).

Anova test showed that there is no significant difference in the mean pre-exercise PGC- $1 \alpha$ levels in all groups $(P>0.05)$. This shows that in this study using the same subject that is obese women in all groups (CON, MIIE and MICE), so the levels of PGC-1 $\alpha$ preexercise did not show a significant difference. Therefore, if there is a change in PGC-1 $\alpha$ levels purely due to the influence of the given exercise. Based on Table 2, ANOVA test results showed that there are no significant differences in PGC-1 $\alpha$ post-exercise levels in all groups $(P>0.05)$. However, when it is viewed from the average value of MIIE, it tends to have a higher PGC-1 $\alpha$ level compared to MICE and CON. These results are in line with the results of research conducted by Norheim et al. (2014) concluded that there was no significant increase in mean PGC-1 $\alpha$ levels after moderate intensity interval training in obese subjects. Likewise research conducted by Leick et al. (2008) using a sample of 


\section{STRADA Jurnal Ilmiah Kesehatan}

DOI: $10.30994 /$ sjik.v9i2.299

ISSN: 2252-3847 (print); 2614-350X (online)

Vol.9 No.2 November 2020 Page.345-352

wistar rats that were given moderate continuous intensity exercise interventions that were carried out acutely using a treadmill also did not show a significant increase in mean PGC$1 \alpha$ levels. However, other studies have found different results that the administration of moderate continuous intensity exercise significantly increases PGC-1 $\alpha$ levels 3 hours and 24 hours after exercise intervention (Shirvani and Arabzades, 2018). But these results contradict the results of research conducted by Taylor et al. (2016) using subjects aged 2535 years old who were given anaerobic training with interval and continuous methods for 3 weeks did not show a significant increase in the mean PGC- $1 \alpha$ levels. Based on previous research, it is showed that the increase in PGC-1 $\alpha$ occurs after exercise 1, 2 and 3 hours (Akimoto et al., 2004) 5 hours (Gibala et al., 2009).

Exercise is a stimulant that is very physiological and involves all body systems, whether muscular, nervous, metabolic systems or the hormonal system (Sugiharto, 2012). The stimulation will be responded by the body in creating homeostasis by secreting myokines. Myokin has an important role as endocrine, paracrine and autocrine (Shirvani and Arabzadeh, 2018). Exercise has been shown to activate the phenotype of brown adipose tissue by increasing PGC-1 $\alpha$ secretion (Popov et al., 2014). PGC- $1 \alpha$ is a transcript regulator that facilitates various transcription factors to regulate the network of highly complex genes involved in mitochonic changes and the formation of brown adipose tissue (Dinas et al., 2017).

Long duration exercises are indicated by contraction of skeletal muscle. Muscle contraction is related to the type of muscle fiber types that are heterogeneous and the recruitment of fiber types depends on the intensity during exercise (Altenburg et al., 2007). Type of muscle fibers I and II with exercise has an important role and both are related to the exercise. Wang and Sahlin (2012) study of muscle fiber types I and II with moderate intensity had a significant difference between the use of muscle fiber types and had no difference in the role of secreting PGC-1 $\alpha$. Muscle fiber type I as the dominant type of muscle fiber is used for long duration sports (Stockdale, 1997) with relatively high mitochondrial and oxidizing properties which is estimated to 20\% and 10\% (Jung and Kim, 2014).

Skeletal muscle plays an important role in exercises stimulated by the brain. The limbic system under the hypothalamus has an important role in digging up memories to make movements that have been performed. Limbik will stimulate the HPA axis (Thomas and Lena., 2010) to regulate the endocrine system and deliver impulses to the cortical premotor as a skeletal muscle drive (Shirvani and Arabzadeh, 2018). In order to contract skeletal muscle, the cortex premotor will stimulate $\mathrm{Ca}^{2+}$ in the muscle as an actin and myosin attachment that will stimulate CaMK to transfer phosphate ATP to serine or seritonin residues (Swulius and Waxham., 2008) with the passage of time the ATP level will be low, which will phosphorylate the ATP phosphate to serine or seritonin residues (Swulius and Waxham., 2008). AMPK (Taylor et al., 2016) to supply energy by stimulating PGC-1 $\alpha$ which plays a role in glucose and fatty acid metabolism (Ljubicic et $a l ., 2010$ ) plays an important role in mitochondrial biogenesis (Pilegaard et al., 2003).

MIIE training in terms of energy system expenditure has greater expenditure than MICE training (Taylor at al., 2016). This situation is a proof that MIIE training in $\mathrm{Ca}^{2+}$ expenditure is greater which can affect energy metabolism in increasing CaMK levels will increase ATP levels as energy in the body (Jung and Kim, 2014). Deposits of ATP will decrease and phosphorylate MAPK, stimulate PGC- $1 \alpha$ as the formation of ATP for the next energy (Karatzeferi et al., 2001). Increased MAPK levels will also increase PGC-1 $\alpha$ levels (Taylor et al., 2016) the increase is 53\% in MIIE (Greenhanff et al., 1994). 


\section{STRADA Jurnal Ilmiah Kesehatan}

DOI: $10.30994 /$ sjik.v9i2.299

ISSN: 2252-3847 (print); 2614-350X (online)

Vol.9 No.2 November 2020 Page.345-352

\section{CONCLUSION}

Based on the results of the study, it is concluded that there are no significant differences in the mean levels of PGC-1 $\alpha$ pre-exercise and post-exercise in all groups $(P>0.05)$. It is recommended to conduct further research by providing moderate intensity treadmill exercise intervention which is carried out chronically to increase PGC-1 $\alpha$ levels.

\section{REFERENCES}

Akimoto, T., Sorg, B. S. and Yan, Z. 2004. Real-Time Imaging Of Peroxisome Proliferator-Activated Receptor-y Coactivator-1 $\alpha$ Promoter Activity in Skeletal Muscles of Living Mice. American Journal of Physiology-Cell Physiology, 287(3): C790-C796.

Altenburg, T. M., Degens, H., van Mechelen, W., Sargeant, A. J. and de Haan, A. 2007. Recruitment of Single Muscle Fibers During Submaximal Cycling Exercise. Journal of applied physiology, 103(5): 1752-1756.

Bell, C.G., Walley, A.J. and Froguel, P. 2005. The Genetics of Human Obesity. Nature reviews genetics, 6(3): 221.

Chooi, Y.C., Ding, C. and Magkos, F. 2019. The Epidemiology of Obesity. Metabolism: Clinical and Experimental, 92: 6-10. https://doi.org/10.1016/j.metabol.2018.09.005

Collison, K. S., Zaidi, M. Z., Subhani, S. N., Al-Rubeaan, K., Shoukri, M. and AlMohanna, F. A. 2010. Sugar-Sweetened Carbonated Beverage Consumption Correlates with BMI, Waist Circumference, and Poor Dietary Choices in School Children. BMC Public health, 10(1): 234.

Daskalopoulou, S.S., Daskalopoulou, S.S., Cooke, A.B., Gomez, Y.H., Mutter, A.F., Filippaios, A., Mesfum, E.T. and Mantzoros, C.S. 2014. Plasma irisin levels progressively increase in response to increasing exercise workloads in young, healthy, active subjects. European Journal of Endocrinology, 171(3). pp. 343-352. https://doi.org/10.1530/EJE-14-0204.

Dinas, P. C., Lahart, I. M., Timmons, J. A., Svensson, P. A., Koutedakis, Y., Flouris, A. D. and Metsios, G. S. 2017. Effects of Physical Activity on the Link Between PGC-1a and FNDC5 in Muscle, Circulating Irisin and UCP1 of White Adipocytes in Humans: A Systematic Review, 6.

Fan, M., Rhee, J., St-Pierre, J., Handschin, C., Puigserver, P., Lin, J. and Spiegelman, B. M. 2004. Suppression Of Mitochondrial Respiration Through Recruitment of p160 my Binding Protein to PGC-1 $\alpha$ : Modulation by p38 MAPK. Genes \& development, 18(3): 278-289.

Franks, P. W., Barroso, I., Luan, J. A., Ekelund, U., Crowley, V. E., Brage, S. and Schafer, A. J. 2003. PGC-1 $\alpha$ Genotype Modifies the Association of Volitional Energy Expenditure with VO2max. Medicine \& Science in Sports \& Exercise, 35(12):1998-2004.

Garawi, F., Devries, K., Thorogood, N. and Uauy, R. 2014. Global Differences Between Women And Men In The Prevalence of Obesity: Is There an Association with Gender Inequality. European journal of clinical nutrition, 68(10):1101-1106.

Gibala, M. J., McGee, S. L., Garnham, A. P., Howlett, K. F., Snow, R. J. and Hargreaves, M. 2009. Brief Intense Interval Exercise Activates AMPK And P38 MAPK Signaling and Increases the Expression Of PGC-1 $\alpha$ in Human Skeletal Muscle. Journal of applied physiology, 106(3): 929-934. 


\section{STRADA Jurnal Ilmiah Kesehatan}

DOI: $10.30994 /$ sjik.v9i2.299

ISSN: 2252-3847 (print); 2614-350X (online)

Vol.9 No.2 November 2020 Page.345-352

Greenhaff PL, Nevill ME, Soderlund K et al., 1994. Themetaboli Cresponses of Human Type I and II Muscle Fibres During Maximal Treadmill Sprinting. J Physiol 478:149-155

Jung, S. and Kim, K. 2014. PGC-1 $\alpha$ Transcription Factors Induced by Exercise in Skeletal Muscle. Penelitian kedokteran integratif, 3(4):155-171

Karatzaferi C, de Haan A, Ferguson RA et al., 2001. Phosphocreatine and ATP Content In Human Single Muscle Fibres Before and After Maximum Dynamic Exercise. Pflügers Arch Eur J Physio, 1442:467-474

Kelly, T., Yang, W., Chen, C. S., Reynolds, K. and He, J. 2008. Global Burden of Obesity in 2005 and Projections to 2030. International journal of obesity, 32(9): 14311437.

Leick, L., Wojtaszewski, J. F., Johansen, S. T., Kiilerich, K., Comes, G., Hellsten, Y. and Pilegaard, H. 2008. PGC-1 $\alpha$ is not Mandatory For Exercise-and Training-Induced Adaptive Gene Responses In Mouse Skeletal Muscle. American journal of physiology-endocrinology and metabolism, 294(2): E463-E474.

Little, J. P., Safdar, A., Cermak, N., Tarnopolsky, M. A. and Gibala, M.J. 2010. Acute Endurance Exercise Increases the Nuclear Abundance of PGC-1 $\alpha$ in Trained Human Skeletal Muscle. American Journal of Physiology-Regulatory, Integrative and Comparative Physiology, 298(4):R912-R917.

Ljubicic, V., Joseph, A. M., Saleem, A., Uguccioni, G., Collu-Marchese, M., Lai, R. Y, and Hood, D. A. 2010. Transcriptional and Post-Transcriptional Regulation of Mitochondrial Biogenesis in Skeletal Muscle: Effects of Exercise and Aging. Biochimica et Biophysica Acta (BBA)-General Subjects, 1800(3): 223-234.

Lobstein, T. and Jackson-Leach, R. 2006. Estimated Burden of Paediatric Obesity and CoMorbidities in Europe. Part 2. Numbers of Children with Indicators of ObesityRelated Disease. International Journal of Pediatric Obesity, 1(1):33-41.

Norheim, F., Langleite, T. M., Hjorth, M., Holen, T., Kielland, A., Stadheim, H. K. and Drevon, C. A. 2014. The Effects of Acute and Chronic Exercise on PGC-1 $\alpha$, Irisin and Browning of Subcutaneous Adipose Tissue in Humans. The FEBS journal, 281(3): 739-749.

Pilegaard, H., Saltin, B. and Neufer, P. D. 2003. Exercise Induces Transient Transcriptional Activation of the PGC-1 $\alpha$ Gene in Human Skeletal Muscle. The Journal of Physiology, 546(3): 851-858.

Popov, D. V., Bachinin, A. V., Lysenko, E. A., Miller, T. F. and Vinogradova, O. L. 2014. Exercise-Induced Expression of Peroxisome Proliferator-Activated Receptor $\Gamma$ Coactivator- $1 \alpha$ Isoforms in Skeletal Muscle of Endurance-Trained Males. The Journal of Physiological Sciences, 64(5): 317-323.

Rachmi, C. N., Li, M. and Baur, L. A. 2017. Overweight and Obesity in Indonesia: Prevalence and Risk FactorsA Literature Review. Public Health, 147: 20-29.

Riskesdas. 2018. Laporan Nasional Riset Kesehatan Dasar. Jakarta: Kemenkes RI. Available at: http://www.kesmas.kemkes.go.id.

Rowe, G. C., Jiang, A. and Arany, Z. 2010. PGC-1 Coactivators in Cardiac Development and Disease. Circulation research, 107(7), 825-838.

Shirvani, H. and Arabzadeh, E. 2018. Metabolic Cross-Talk Between Skeletal Muscle and Adipose Tissue In High-Intensity Interval Training Vs. Moderate-Intensity Continuous Training by Regulation Of PGC-1 $\alpha$. Eating and Weight DisordersStudies on Anorexia, Bulimia and Obesity, 1-8. 


\section{STRADA Jurnal Ilmiah Kesehatan}

DOI: $10.30994 /$ sjik.v9i2.299

ISSN: 2252-3847 (print); 2614-350X (online)

Vol.9 No.2 November 2020 Page.345-352

Stockdale, F. E. 1997. Mechanisms of Formation of Muscle Fiber Types. Cell Structure and Function, 22(1): 37-43.

Sugiharto and andiana O. 2006.The Effects Respon and Creatin Kinase in White Wistar Rats.Folia Medica Indonesia, 42(4): 228-232.

Swulius, M. T. and Waxham, M. N. 2008.Ca 2+/Calmodulin-Dependent Protein Kinases. Cellular and Molecular Life Sciences, 65(17): 2637.

Taylor, C. W., Ingham, S. A., Hunt, J. E., Martin, N. R., Pringle, J. S. and Ferguson, R. A. 2016. Exercise Duration-Matched Interval and Continuous Sprint Cycling Induce Similar Increases in AMPK Phosphorylation, PGC-1 $\alpha$ And VEGF Mrna Expression in Trained Individuals. European journal of applied physiology, 116(8): $1445-1454$.

Thomas, G.G. and Lena, E. 2010. Chronic Stress And The Hpa Axis: Clinical Assessment And Therapeutic Considerations. A review of natural and nutraceutical therapies for clinical practice, 9.

Tsuchiya, Y., Ando, D., Goto, K., Kiuchi, M., Yamakita, M. and Koyama, K. 2014. Highintensity exercise causes greater irisin response compared with low-intensity exercise under similar energy consumption. The Tohoku journal of experimental medicine, 233(2): 135-40. https://doi.org/10.1620/tjem.233.135.

Wang, L. and Sahlin, K. 2012. The Effect of Continuous and Interval Exercise on PGC-1 $\alpha$ and PDK4 Mrna In Type I and Type II Fibres of Human Skeletal Muscle. Acta physiologica, 204(4): 525-532.

Wright, D. C., Han, D. H., Garcia-Roves, P. M., Geiger, P. C., Jones, T. E. and Holloszy, J. O. 2007. Exercise-Induced Mitochondrial Biogenesis Begins Before The Increase In Muscle PGC-1 $\alpha$ Expression. Journal of Biological Chemistry, 282(1): 194-199 